http://dx.doi.org/10.18778/1509-877X.2018.02.02

\title{
China's Tax and Non-tax Instruments RESPONDING TO ITS WEAKENING Attractiveness to Foreign Capital
}

Summary. This paper studies China's weakening in its attractiveness to foreign capital, especially since its implementation of new corporate income tax law in year 2008, which phased out the former preferential tax treatments for foreign invested enterprises and the placed-based favourable tax policies for various special tax zones. Empirical evidence and the major factors causing this weakening in attracting foreign investment are discussed. This paper also studies the major tax measures, fiscal measures and non-tax measures adopted by China central and regional governments, which are aimed to improve China's competitiveness in attracting foreign capital. The major contribution of this paper is its discussion on China's good practice of making use of nontax measures to attract foreign capital, which is effective in avoiding harmful international tax competition. The other contribution of this paper is the discussion on the economic foundation (i.e. China's comparative strength and state ownership of lands) which makes these non-tax measures feasible. China's good practice of adopting non-tax measures and making use of its comparative strength is of reference value to other capital importing countries in the world.

Keywords: attractiveness to foreign capital, non-tax measures, comparative advantage

* The author would like to express her gratitude to Prof. Dr. Ziemowit Kukulski for his advice. The author is a fellow researcher in Centre of Tax Documentation and Studies of University of Lodz, and also an assistant professor of the Public Finance and Administration School of Shanghai Lixin University of Accounting and Finance (Shanghai, China), e-mail: 20149018@lixin.edu.cn 
Formulation of competitive policy instruments to attract foreign direct investment is a very important issue for many countries, including but not limited to developing countries. Among the developed countries, the United States under the leadership of President Donald Trump pays much attention to this issue by implementing a tax cut reform to attract capital flow into its territory and sees it as a measure to revive its manufacturing industry.

In practice, governments in various countries prefer to create some special tax zones ${ }^{1}$ and take measures to encourage new business investments, i.e. available lands, fundamental infrastructure and favourable tax policies. These measures are usually appealing to foreign investors given other conditions for doing business also being acceptable.

As a possibly effective platform for attracting foreign capital and develop regional economy, special economic zones are viewed as an interesting topic by many scholars. Jarosiński et al. (2016) studied the impact of special economic zones on regionally social and economic development and also the influence on foreign direct investment and the improvement of job market situation ${ }^{2}$. Ahrens et al. (1995) noticed that in the course of Central and Eastern Europe's transformation process special economic zones both accelerated transformation and attracted foreign investment, but they also experienced failure in some countries or regions ${ }^{3}$. Besides special economic zones, Ahrens et al. (1995) also studies the export processing zones experiences in South Korea, Mauritius, Mexico and India ${ }^{4}$. Smętkowski (2002) examined the general impacts of special economic zones in Poland and evaluated the results of these zones as instruments for enhancing regional development and industry development ${ }^{5}$. Laukkanen (2016) compared the difference

1 These special tax zones consist of free trade zones, export processing zones, high technology zones, etc.

${ }^{2}$ K. Jarosiński, G. Maśloch, The Impact of Special Economic Zones on the Level of Socio-Economic Changes of Polish Regions, Warsaw Forum of Economic Sociology, Autumn 2016, vol. 7, no. 2 (14), pp. 115-137.

3 J. Ahrens, A. Meyer-Baudeck, Special Economic Zones: Shortcut or Roundabout Way towards Capitalism, "Intereconomics”, March/April 1995, pp. 86-95.

4 Ibidem.

${ }^{5}$ M. Smętkowski, Polish Special Economic Zones as an Instrument of Regional and Industrial Policy, "Munich Personal RePEc Archive", online at http://mpra.ub.unimuenchen.de/39184/ (accessed: 15.04.2018), MPRA Paper No. 39184, posted on 19 June 2012, pp. 1-12. 
between special tax zones and tax heavens, discussed the major tax and business characteristics of special tax zones via comparison of the experiences in ten jurisdictions, and also looked into economic development of special tax zones in different stages ${ }^{6}$. Lipták et al. (2015) discussed the legal matters with respect to the formation of special economic zone under the framework of European Union Law, examined the imbalanced development level among observed countries (around 30 countries) using cluster analysis method, and put forward a suggestion that it might have more potential for some countries to form special economic zones in the explored areas ${ }^{7}$. It is worthy of noting that the tax breaks and tax exemption applying in special economic zones located in Poland or other member states of European Union (abbreviated as "EU") face a legal risk of being viewed as "state aid", which are seen as a breach of the EU laws unless these tax incentives satisfy certain conditions such as for the purpose of alleviating poverty or underemployment in a certain region or for the purpose of promoting a project of common European interest, etc. (Lipták et al., 2015; Laukkanen, 2016; Jarosiński et al. 2016; Smętkowski, 2002).

Zheng et al. (2016) found out that at the macro-level the development zones' overall contribution to regional economic growth is not in commensurate with their share of land in host cities which implies that China's central government should pay more attention to the efficiency of these zones by considering their size and location before ratifying the formation of these zones and should not expand the size of these zones without any limit ${ }^{8}$. Zhang (2011) studied China regional governments' irrational expenditures in infrastructure aimed to form development zones, among which many of these zones were idle and did not attract any business capital inflow, and in view of this negative effect, Zhang (2011) suggested that the central government should interfere with the abuse of land by regional governments via tax or fiscal instruments. ${ }^{9}$ Huang et al. (2016)

6 A. Laukkanen, The Development Aspects of Special Tax Zones, "Bulletin for International Taxation" 2016, vol. 70, no. 3, pp. 152-162.

7 F. Lipták, S. Klasová, V. Kováč, Special Economic Zone Constitution According to Cluster Analysis, "Procedia Economics and Finance" 2015, no. 27, pp. 186-193.

${ }^{8}$ G. Zheng, E. Barbieri, M.R. Di Tommaso, L. Zhang, Development Zones and Local Economic Growth: Zooming in on the Chinese Case, "China Economic Review" 2016, vol. 38 , pp. $238-249$.

9 J. Zhang, Interjurisdictional Competition for FDI: The Case of China's "Development Zone Fever", "Regional Science and Urban Economics" 2011, vol. 41, pp. 145-159. 
compared the land use efficiency of electronics firms located inside and outside development zones in Shanghai and his research outcome revealed that electronics firms inside development zones are more efficient than those outside these zones in terms of land use, and this differentiation was attributed to government supports, technological externalities and international linkages benefiting the firms inside these zones ${ }^{10}$. Wang (2013) conducted an empirical study to a set of Chinese dataset at municipal level and found out that the programs / projects within Chinese special economic zones enhanced foreign direct investment, however, for zones established later the benefits in economic growth and wage increase were smaller while the distortions in firm location behaviour were larger than those zones set up earlier, furthermore, municipalities with multiple special economic zones experienced bigger effects than those with only one zone ${ }^{11}$. Sosnovskikh (2017) made an investigation to Russia's formation and operation of special economic zones and the result revealed that Russia's policies aimed to encourage export, job creation and technology / knowledge diffusion had strongly interfered with business's activities and thus prevented business from conducting competition and collaboration within these zones ${ }^{12}$. Parwez and Sen (2016) discussed the negative effects linked with the land supply in India for the creation of special economic zones, emphasized that governments' forcible acquisition of agriculture lands from local farmers had caused large-scale unemployment and sometimes the lands were not used for intended productive sectors and infrastructure but for real estate projects or even remained unutilized ${ }^{13}$.

China has already established hundreds of zones since its implementation of openness and reform strategy around four decades ago. The types of these zones in China are very diversified, ranging from special economic zones, free trade zones, coastal economic openness zones, highly technological zones, economic and technology development zones, export

10 Z. Huang, C. He, Y.H.D. Wei, A Comparative Study of Efficiency of Electronics Firms Located within and outside Development Zones in Shanghai, "Habitat International" 2016, vol. 56, pp. 63-73.

11 J. Wang, The Economic Impact of Special Economic Zones: Evidence from Chinese Municipalities, "Journal of Development Economics" 2013, vol. 101, pp. 133-147.

12 S. Sosnovskikh, Industrial Cluster in Russia: The Development of Special Economic Zones and Industrial Parks, "Russian Journal of Economics" 2017, vol. 3, pp. 174-199.

13 S. Parwez, V. Sen, Special Economic Zone, Land Acquisition, and Impact on Rural India, "Emerging Economy Studies" 2016, vol. 2 (2), pp. 223-239. 
processing zones, and new development areas. Similar to the practice in other countries as mentioned above, China granted various tax incentives to the foreign invested enterprises located within these zones. These tax breaks and tax exemption / reductions are essentially distinguished depending on the type of these zones. These tax incentives caused tax inequity between foreign invested enterprises and domestic enterprises and also led to regionally economic imbalance as most of the earlier created special tax zones are located in eastern China rather than in central or western China.

Under the pressure of improving tax equity and eliminating regionally economic disparity, in year 2008 China phased out its previously dual income tax systems ${ }^{14}$ : one corporate income tax system solely for foreign invested enterprises and the other corporate income tax system only for domestic invested enterprises. It also abandoned the place-based favourable tax treatments for the special tax zones located in China's eastern regions. As a replacement of its previously distinguished dual corporate income tax regimes, China unified its corporate income system for both foreign invested enterprises and domestic invested enterprises, and also unified its corporate income treatments for enterprises located in different regions of China including various special tax zones but excluding western regions.

Ten years have passed since China's gradual phasing out of its favourable corporate income tax system for foreign invested enterprises and for special tax zones as of early 2008. Does this phasing out of favourable tax policies for foreign capital cause any results?

Apparently, in recent years, as reported by newspaper and observed by ordinary people, China has experienced a notable weakening in its attractiveness to foreign capital, especially after it phased out the preferential corporate income tax policies for foreign invested enterprises and the placed-based favourable tax treatments for various special tax zones. Consequently, both China central government and regional governments have to confront an unavoidable issue - how to deal with the weakening of competitiveness in attracting foreign capital?

In order to seek for the answer to this issue, this paper will discuss the central government's and regional governments' recently released tax and

${ }^{14}$ Under this tax reform, China granted a five-year transitional period to those foreign invested enterprise, which were applicable to preferential treatments under the former Foreign Invested Enterprise Income Tax Law. 
fiscal measures as well as other non-tax measures which are aimed to offset the weakening of China's attractiveness to foreign capital.

What makes this research meaningful is that China governments' efforts to deal with the weakening in its attractiveness to foreign capital contribute good practice and also offer lessons for other capital-importing countries. For instance, Poland intends to phase out its special tax zones after year 2020 and hence afterwards it will have to face the decline in its attractiveness to foreign capital due to its proposed repeal of the former preferential tax policies applying in its special tax zones.

This paper is also distinguished from other studies in its emphasis on the non-tax measures adopted by China governments. These non-tax measures do not seem to cause harmful international tax competition, but they are still face the risks of being criticized for offering state aid to certain industries or certain enterprises which will cause unfair market competition between China and other so called free market economies, even though technically speaking the fairness in competition is just a relative concept rather than an absolute concept. The state aid offered by China governments might cause international trade conflicts launched by its rivals in the world. The recent trade war launched by the United States against China is one example of this.

Except for certain measures of fiscal subsidy nature (or called as "state aid" by European Union law), some of China's good practice is feasible to other capital importing countries and also acceptable for free market economies, such as simplifying and optimizing public administration to foreign investors, encouraging research and innovation and improving transparency and fairness in governmental procurement.

\section{Discussion on China's Weakening in Its Attractiveness TO Foreign CAPital}

China's competitiveness in attracting foreign capital has been decreasing gradually for a few years. This weakening in its attractiveness was clearly visible from three dimensions: the decreasing annual foreign investment amount, the decreasing number of foreign invested manufacturing enterprises and the labour emigration from China's eastern region to central and western areas. Most of special tax zones created at an earlier stage were located in eastern areas. This weakening in its attractiveness was mainly caused by the overall increment in the cost of doing business in China which impaired the profitability of business. Detailed discussion on this issue is set out as follows. 
2.1. Empirical Evidence on the Weakening Attractiveness to Foreign Capital

China's actual use of foreign investment amount in year 2016 was less than that of the previous year by USD 266 million (minus $0.2 \%$ growth rate). Its number of foreign invested manufacturing enterprises was undergoing a continuous decline trend since 2008 (see the following Figure 1). Furthermore, China's flowing labour force (note: mainly consisting of idle peasants) showed a trend of flowing from the eastern region to its central and western region. For instance, the inflow of labour force to central region in year 2017 increased by $2.9 \%$ compared with year 2016; the inflow of labour force to western region in year 2017 increased by $4.9 \%$ compared with year 2016; but the inflow of labour force to eastern region in year 2017 increased by only $0.2 \%$ compared with year 2016 .

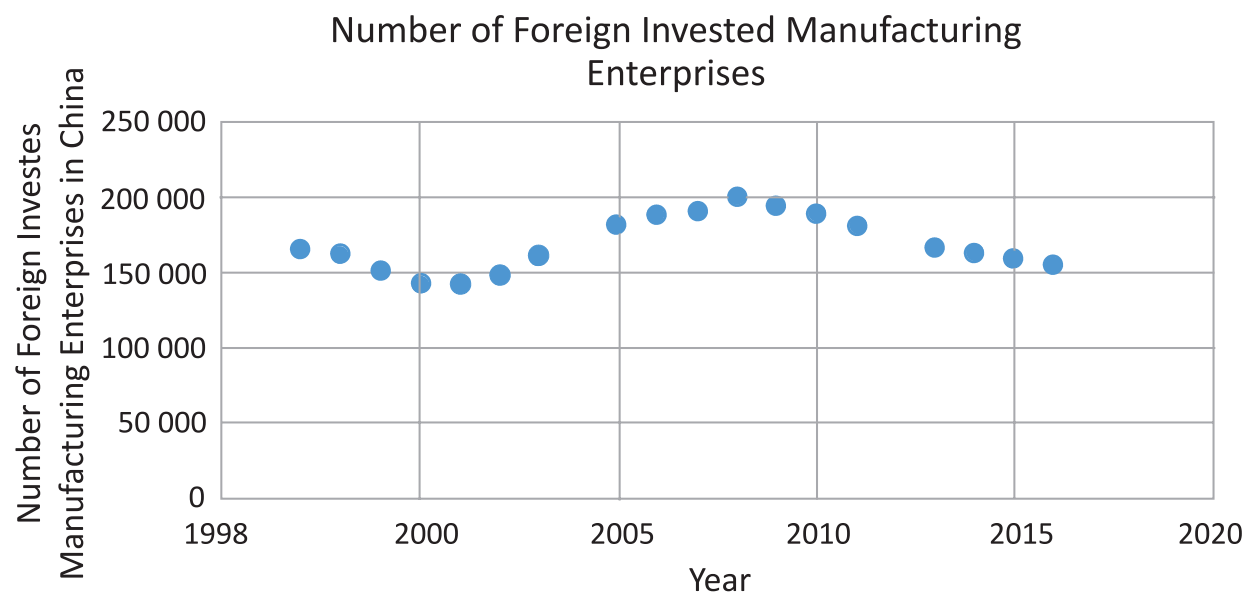

Figure 1

Source of data: the PRC National Statistics Bureau, http://www.stats.gov.cn/ (accessed: 12.12.2019).

2.2. Discussion on the Factors that Eroded China's Attractiveness to Foreign Capital

Theoretically speaking, China's decline in its attractiveness to foreign investment is mainly caused by the gradual increase of the overall business operation cost in China. This overall business operation cost could be roughly divided into five costs: tax and fee cost, labour cost, land cost, 
financing cost, as well as law and regulation compliance cost. In general, tax cost is generally measured by effective tax burden and fee costs in China usually involve non-tax revenue items which are consolidated into the government's general budget and other user fees mainly consisting of the "Governmental Fund Items" which are of the nature of earmarked taxes and are not lawfully included in the tax system but still contained in the government fiscal budget (called as the "Governmental Fund Budget"). Labour cost usually is measured by average labour wage level. Land cost is measured by average land price, which in practice is categorized into four kinds of prices: overall average land unit price, commercial land unit price, residential land unit price and industrial land unit price. Financing cost is usually measured by interest rate and relevant handling fee rate charged by various financial institutions. The cost of complying with law and regulation is measured by the time cost wasted by enterprises on the time-consuming documentation preparation, application and negotiation procedures with government authorities and the lengthy ratification procedures by various levels of government authorities.

\subsubsection{The Repeal of the Former Tax Incentives for Foreign Invested Enterprises, Foreign Investors and Special Tax Zones}

China's former favourable tax incentives solely granted to foreign invested enterprises were phased out since the enforcement of a unified corporate income tax (hereafter abbreviated as "CIT") law for both domestic and foreign enterprises as of 1 January 2008. Year 2008 is a dividing line in terms of the special tax treatments granted to foreign capital enterprises. Prior to 2008, China granted preferential corporate income tax (“CIT") treatment with the CIT rate being reduced to $15 \%$ for foreign invested enterprises who were located in special economic zones. Foreign invested manufacturing enterprises located in economic and technological development zones also enjoyed a reduced CIT rate of $15 \%{ }^{15}$. Foreign invested enterprises located in coastal economic openness areas or urban areas (outside captive special tax zones) of cities where these cities have economic special zones or economic technology development zones enjoyed

15 Article 7 of Foreign Invested Enterprise and Foreign Enterprise Income Tax Law of the People's Republic of China (hereafter abbreviated as "FEIT Law"), ratified by the $4^{\text {th }}$ Conference of the $7^{\text {th }}$ National People's Congress, released on 9 April 1991 and enforced on 1 July 1991. 
a reduced CIT rate of $24 \%{ }^{16}$. Favoured projects such as energy projects, transportation projects, harbours and wharfs which were located in coastal economic open areas, economic special zones and old urban areas of the cities which have economic and technology development zones, were also applicable to a reduced CIT rate of $15 \%{ }^{17}$.

Besides lower CIT rate, the production-oriented foreign invested enterprises also enjoyed tax holiday, i.e. " 2 years exemption and 3 years $50 \%$ deduction of CIT" since their first profit-making years (after offsetting their previous years' losses carried forward).

Prior to year 2008, China also applied favourable tax treatment to foreign investors. For instance, if the foreign investors of the foreign invested enterprises in China intended to reinvest their earned after tax profits sourced from these enterprises in China in the form of increasing these China incorporated enterprises' registered capital or re-establishment of new foreign invested enterprises in China with the proposed operation period of these new enterprises being no shorter than five years, $40 \%$ of the paid China corporate income tax linked with these China-sourced after tax profits may be refunded to these foreign investors upon both their application and the approval by their in charge China tax authorities ${ }^{18}$. China government also waived the withholding tax on the dividend earned by these foreign investors from their invested subsidiaries in China ${ }^{19}$.

However, after year 2008, the CIT rate for either foreign invested enterprises or domestic enterprises was unified to a standard rate of $25 \%$. Before year 2008, the enterprise income tax rate for domestic capital enterprises was 33\%, much higher than that for foreign capital enterprises. Even though there was still a transitional period of 5 years for foreign invested enterprises to increase its CIT rate from $15 \%$ to $25 \%$ gradually, after year 2012 all the above territorial-based CIT preferential treatments granted to foreign capital enterprises were phased out. Even though the unified CIT Law enforced since 1 Jan 2008 still stipulates some preferential tax treatments for some specific industries (Hi-tech industry, environment-friendly industry, venture capital, infra structure and so on), these treatments are no longer based on or no longer linked to any special tax zones except for the tax incentives aimed to support the economic growth of less developed
16 Article 7 of FEIT Law.
7 Article 7 of FEIT Law.
18 Article 10 of FEIT Law.
19 Article 19.1 of FEIT Law. 
western regions. This substantial transformation in CIT policy weakened China market's attractiveness to foreign capital. Some big-sized foreign enterprises have chosen or are considering moving out of China and then rebuild premises in other jurisdictions such as countries in South East Asia or South Asia, which promise to offer more favourable CIT treatments. For instance, Nike closed its only one shoe production factory in China and laid down 1400 employees in year 2009; Adidas closed its only one shoe production factory in China in year 2012 and also determined to move its production lines to Myanmar, one country located in south east Asia; Samsung formally closed its internet device equipment production company located in Shenzhen City on 27 April 2018 and laid down 320 employees $^{20}$.

In order to curb this emigration of enterprises from China, some tax experts in China did some studies and proposed to introduce an "exit tax" to tax resident in China. However, if the shareholders of existing foreign enterprises (note: some of the individual shareholders are China tax residents, particularly the China shareholders of China-foreign capital joint ventures and the ultimate China shareholders of some "faked" foreign invested enterprises ${ }^{21}$ ), perceive the risk of being imposed of exit tax, they will accelerate their capital outflow from China and this possible large scale foreign capital outflow is quite risky for China in terms of the potential tax revenue outflow or the underlying foreign currency reserve pressure. Since a formal imposition of a new tax usually takes at least three or more years to persuade the relevant interest groups, deal with their lobbying activities and pass the legislation procedures, it does not seem to be realistically feasible for China to view this proposed "exit tax" as an effective instrument to curb current foreign capital outflow.

\subsubsection{The Continuous Increment of Labour Cost}

China's existing Labour Law is biased to protect the rights of work force rather than the employers' rights. The average age for work force in China is aging. Both two reasons accelerate a continuous rise of labour cost in China's foreign invested enterprises (see the following Figure 2).

20 See: Wu Xiaobo, Foreign Capital Is Flowing Out of China and Why?, "Finance and Economy First We Media - Wu Xiaobo Channel”, 6 May 2018.

21 These faked foreign invested enterprises had foreign individual shareholders in its legal incorporation document but the ultimately real individual shareholders behind these symbolic foreign individual shareholders were Chinese. 


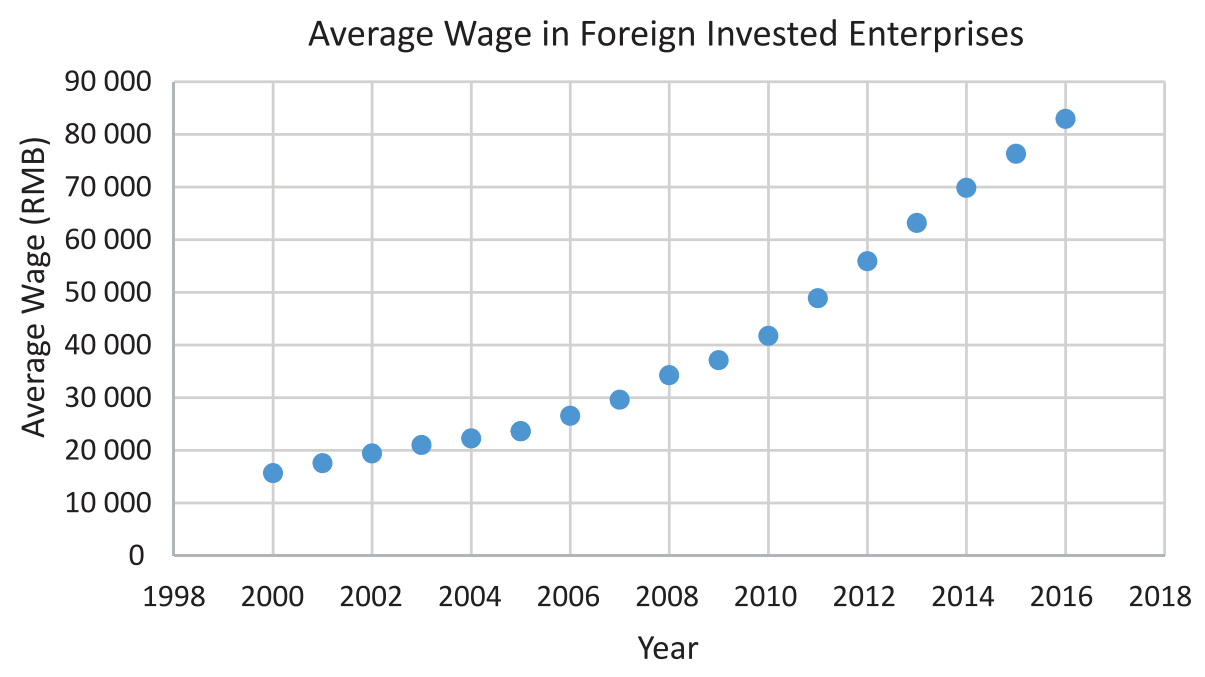

Figure 2

Source of data: the PRC National Statistics Bureau, http://www.statistics.gov.cn (accessed: 9.05.2018).

2.2.3. The Increasing Land Cost

In the past years, China's land costs increased rapidly (see Figure 3 ). The increase in land costs was partly driven by local governments' behaviours in seeking for "Land Fiscal Revenues". Under China's land monopoly supply system, local government is almost the only one land supplier in the land market. Local governments gained huge fiscal revenue through buying agricultural lands from farmers or residential lands from urban residents at a lower price and then selling to real estate developers at a much higher price after considering local governments' cost in serving these lands with necessary utilities services. Chinese scholars call this kind of local government revenue sourced from supplying land to market as "Land Fiscal Revenue".

Even though the industrial land price did not seem to increase rapidly since 2004 to 2018, the commercial land price and residential land price increased significantly since 2004 to 2018, and accordingly the rise in land prices caused the costs for living and doing business increased. The burden of cost increment was consequently passed on to manufacturing industries in the form of increasing labour cost (note: to cover labour's residential rent increment), increasing costs in procurement of goods and services supplied by commercial sectors or service sectors (note: the rent cost for these commercial sectors or service sectors also increased). 


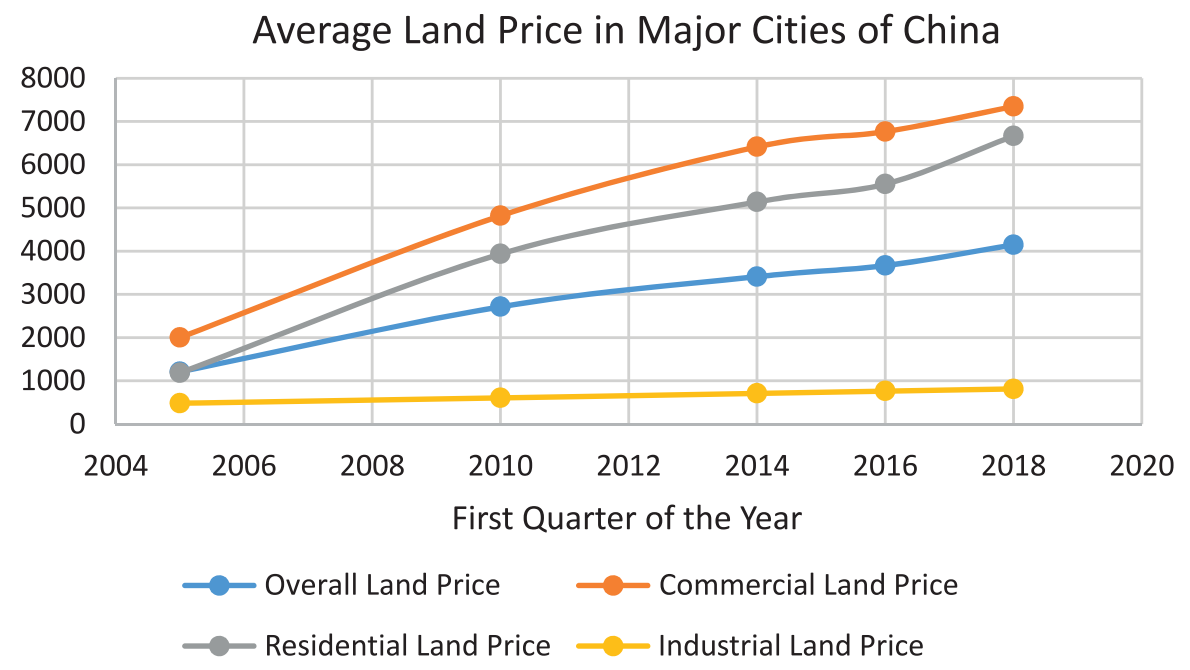

Figure 3

Source: The data for the first quarter of year 2005 is quoted from "The City Land Price Dynamic Monitor Report for the First Quarter of year 2005" (hereafter abbreviated as “Report Q1/2005”), released on 2 October 2005. The data for the first quarter of year 2010, 2014 and 2018 is sourced from Report Q1/2010, Report Q1/2014, Report Q1/2016 and Report Q1/2018 respectively. All the data is available on the website of China Land Price

Information Service Platform, http://www.landvalue.com.cn (accessed: 7.05.2018).

\subsubsection{The High Compliance Cost}

The compliance costs for foreign invested enterprises in China are relatively high. The registration and operation of a foreign invested enterprises needs time-consuming and money-consuming application procedures which involves numerous authorities inclusive of industrial and commercial administration bureau, foreign economic and trading committee (later renamed as the subordinated branches of Ministry of Commerce), tax authority, environment protection bureau, social security bureau, fiscal bureau, public security bureau and other relevant authorities. An enterprise is obliged to handle the registration with these authorities, to comply with tax filing obligations, to contribute social security fees and comply with labour law obligations, to submit financial reports in due time, etc. In practice, some of foreign enterprises have to engage accounting firms or law firms or employ in-house accounting / law staff to handle some of these issues and of course also have to pay professional fees or salaries to them. Foreign enterprises also have to deal with the routine and non-routine investigations conducted by these governmental authorities, such as tax audit, 
environment protection investigation, fire protection check, etc. In order to be well prepared to deal with these governmental investigations, foreign enterprises need to spend extra human resources on these compliance matters. If some of these enterprises fail to pass one or more than one of these governmental investigations, they usually are imposed of fines.

\subsubsection{The High Financing Cost}

Finally, the financing costs for enterprises are relatively high in current China. Banks prefer to offer loans to state-owned enterprises. It is difficult for medium and small sized enterprises to look for loans from banks since in practice these medium and small sized enterprises cannot afford to buy immovable properties whilst the immovable properties are the commonly accepted assets as guarantee for applying for loans from commercial banks. These medium and small sized enterprises were forced to borrow money from private capital market while the actual interest rate of borrowing money from private capital market is far higher than the loan interest rate offered by commercial banks. According to a survey conducted by Chinese Academy of Fiscal Sciences, "state-owned enterprises are easier to obtain financing funds than private-owned enterprises. Around $52.1 \%$ of state-owned enterprises participating in the survey admitted they did not face any difficulty in financing, but only $38.6 \%$ private-owned enterprises participating in the survey expressed that they did not face any problem in seeking for financing. Among the sample enterprises, the weighted average bank loan interest rate for state-owned enterprises in year 2016 was 5.26\% while the interest rate for private-owned enterprises was $6.79 \%$ "22.

The aforementioned five factors pushed the tax burden and cost of running an enterprise in China increased greatly in recent years. These factors have visibly lowered the profitability level of foreign invested enterprises in China. Undoubtedly, profitability level is a key indicator to measure China's attractiveness to foreign capital. In this sense, China government has been forced to implement various measures to offset the negative effect on profitability caused by these factors.

22 Journalist Du Tao, The Differential in Financing Costs Among Enterprises Is Big, and the Difficulty and High Cost in Financing for Medium and Small Size Enterprises are more and more Notable, Published on "Economic Observer", https://finance.sina.cn (accessed: 7.05.2018). The data was originally sourced from the Report namely "Reduction of Costs: 2017 Survey and Analysis" by Chinese Academy of Fiscal Sciences, https://finance.sina.cn (accessed: 7.05.2018). 
3. China Governments' Efforts to Offeset the Weakening in Their Attractiveness to Foreign Capital Through Tax and Non-tax Policies

Since after the year of 2008 there was no special CIT treatments in these zones, it is more appropriate to call the above special tax zones as "Development Zones" after the year of 2008.

In order to offset the weakening in China's attractiveness to foreign capital, for the past two years, China government at various levels has initiated to offer various fiscal subsidies and tailor-made public services to the enterprises (including both domestic and foreign invested enterprises) which register and situate in these special development zones, inclusive of discounted land prices, discounted rent prices, discounted loan interest, high quality schooling opportunities for children of the top management of these enterprises, priorities in selecting and cultivating potential IPO companies, fiscal subsidies in cultivating high-tech enterprises and so on. The following parts of this paper will discuss these tax measures and nontax measures in detail.

\subsection{The Central Government's Several Measures Aimed to Expand Openness and Proactively Make Use of Foreign Capital}

The State Council issued a circular namely "The Notice on Several Measures Aimed to Expand Openness and Proactively Make Use of Foreign Capital" (Circular Guofa [2017] No. 5, hereafter called as "Circular 5"). In this Circular 5, some measures are implemented aimed at expanding openness, improving fair competition environment and attracting foreign investment. These measures are set out in detail as follows.

\subsubsection{Measures to Further Expand Openness to the World}

Circular 5 is guided by the mindset of openness and development and is aimed to push a new round of high level openness to the world. Under Circular 5, the industrial catalogue of foreign investments and its relevant regulations will be amended in order to loosen the foreign capital access constraints in service industry, manufacturing industry, mineral exploitation industry and other industries. Circular 5 also mentions China governments' supports for foreign capital's participation in the implementation of the nation's innovation-driven development strategy, the transformation and 
upgrading of manufacturing industry as well as facilitating talented persons' going back from abroad to start their business in China ${ }^{23}$.

A few detailed measures are formulated in Circular 5 in order to deepen China's openness of service industry to foreign capital, which contains loosening the limitation for access to the business of financial services, accounting and audit services, architecture design, ranking assessment services, and permitting the openness in some industries such as telecommunication, internet, culture, education industry, traffic and transportation industry ${ }^{24}$.

The foreign capital access constraints are cancelled in some fields of the manufacturing industry, including the manufacturing of railway traffic equipment, the manufacturing of motorcycles, the production of fuel ethanol, oil processing, etc. Foreign capital access constraints in some fields of mineral exploitation industry, such as oil shale, oil sand and shale gas as well as other unconventional oil and gas mineral are also loosened ${ }^{25}$. The joint venture cooperation projects involving both foreign and domestic capital in the fields of petroleum and natural gas are not required to obtain governmental approval any longer but only required to submit files to the authorities for record purpose.

Both foreign investment enterprises and domestic enterprises are applicable to policies and measures under the "China Manufacturing Strategy 2025". Foreign capital is encouraged to invest in high end manufacturing, intelligent manufacturing and green manufacturing and other manufacturing sectors. In order to transform and upgrade traditional industries, foreign capital is also encouraged to invest in production-linked service industries, including industrial design and originality design, project advisory services, modern logistics, examination, testing and certification services $^{26}$.

Foreign capital is also supported to participate in infrastructure construction in the form of franchise operation, which involves business such as energy, traffic, irritation works, environment protection, municipal utilities, etc. ${ }^{27}$

${ }^{23}$ See Article 1 of Circular 5. These talented persons generally have Chinese background.

24 Article 2 of Circular 5.

25 Article 3 of Circular 5.

26 Article 4 of Circular 5.

27 Article 5 of Circular 5. 
China governments allow the R\&D cooperation between both domestic and foreign enterprises as well as scientific research institutions. Foreign investment enterprises are supported to build up their R\&D centres, enterprise technology centre and set up their post-doctoral scientific work station. According to the principle of reciprocity, foreign investment enterprises are allowed to participate in the undertaking of projects funded by national scientific technology plans. Foreign investment enterprises are also equally applicable to preferential policies entitled to extra-deduction of R\&D expenditures, high-tech enterprises and R\&D centres ${ }^{28}$.

China governments formulate measures to support overseas high-level talent to start their business in China. These high-level talent expatriates, who hold expatriate permanent residence permits and start their technological business within the territory of China, are entitled to equal treatments as Chinese citizens. Relevant authorities offer facilities as stipulated by laws and regulations to these high-level expatriates and their spouses and children in the course of their application of multiple entry visa or residence permits ${ }^{29}$.

3.1.2. Measures to Further Create a Fair Competition Environment

When government's authorities formulate foreign investment relevant policies, they shall implement fair competition review mechanism according to "State Council's Comments on the Establishment of Fair Competition System under the Construction of Market System" (Circular Guofa [2016] No. 34), call for public opinions in principle and apply for the State Council's approval where important matters are involved. Authorities in every region and locality shall strictly implement national policies and regulations, ensure the consistence in their implementation, and be prohibited from imposing unauthorized new restrictions to foreign investment enterprises ${ }^{30}$.

Government's authorities shall follow the principle of unified standard and unified time limit for both domestic and foreign investment enterprises when they review the applications for business licenses and qualification certificates submitted by foreign investment enterprises, and enhance equal treatment and fair competition between domestic enterprises and foreign enterprises ${ }^{31}$.
28 Article 6 of Circular 5.
29 Article 7 of Circular 5.
30 Article 8 of Circular 5.
31 Article 9 of Circular 5. 
Foreign investment enterprises are allowed to equally participate in the bids for governmental procurement. The products produced by foreign investment enterprises within the territory of China shall be treated equally. The governmental procurement reform shall be deepened. The principle of openness and transparency as well as fair competition shall be adhered to ${ }^{32}$.

Foreign investment enterprises' intellectual properties shall be protected $^{33}$. Foreign investment enterprises will be supported to expand their financing channels. They are allowed to have their initial public offering (hereafter abbreviated as "IPO") in Main Board, Small and Medium Enterprise Board, as well as Growth Enterprises Market, be traded in the new OTC (Over the Counter Market), issue enterprise bonds, company bonds, convertible bonds and make use of non-financial-enterprise debt financing instruments to satisfy their financing ${ }^{34}$.

The reform of foreign investment enterprise capital contribution system shall be deepened by removing the minimum contribution capital limit for foreign investment enterprises and then implementing a unified capital contribution system for both domestic and foreign capital ${ }^{35}$.

\subsubsection{Measures to Further Enforce the Work of Attracting Foreign Capital}

Every region in China is encouraged to carry on investment promotion activities based on the development mindset which emphases innovation, harmonization, green, openness and sharing, depending on its regional situation. Every regional government is allowed to formulate preferential policies within its legal framework. Projects which might hopefully make significant contribution to employment, economic development and technological innovation shall be supported. Regional governments shall take actions to reduce enterprises' investment costs and operation costs, protect the interests of both foreign investment enterprises and their investors and create a good investment environment ${ }^{36}$.

China governments shall support the central and western regions as well as north eastern region to attract the foreign invested industries

32 Article 11 of Circular 5.

33 Article 12 of Circular 5.

${ }^{34}$ Article 13 of Circular 5.

35 Article 14 of Circular 5.

36 Article 15 of Circular 5. 
which are being transferred from the eastern region. The central government shall amend the "Foreign Invested Advantageous Industry Catalogue for the Central and Western Areas" and expand the scope of the encouraged foreign investment projects in central and western areas. The foreign invested enterprises falling within the encouraged category and meeting requisite conditions shall be entitled to preferential CIT policy. The foreign invested enterprises being transferred from the eastern region to the central and western areas and north east area shall enjoy preferential fiscal policy and land supply policy ${ }^{37}$.

In order to enhance the centralized operation of funds both reserved and denominated in domestic currency and foreign currency by multinational companies, facilitate fund flow into China and out of China, improve fund use efficiency and offer investment facilities, China governments determine to proactively attract multinational companies to establish regional headquarters, procurement centres and settlement centres and other functional establishments ${ }^{38}$.

In Circular 5, China central government also formulates measures to support foreign investment projects through land supply, improvement of foreign debt administration system and deepening the reform of foreign investment administration system ${ }^{39}$.

3.2. The Central Government's Several Measures to Enhance the Rise of Foreign Capital Investment

The State Council released one "Notice on Several Measures to Enhance the Increase of Foreign Capital Investment" (Circular Guofa [2017] No. 39, hereafter called as "Circular 39") on 8 August of 2017. This circular establishes national-level measures from five perspectives, inclusive of mitigating the limitation for foreign capital's access to China market, formulating fiscal and tax preferential policies, improving the comprehensive investment environment for national-level development zones, facilitating qualified expatriates' entry to China as well as optimizing business environment. The detailed measures adopted by Circular 39 are set out as follows:

37 Article 16 of Circular 5.

38 Article 18 of Circular 5.

39 Article 17, 19 and 20 of Circular 5. 
3.2.1. Measures to Mitigate the Limitation for Foreign Capital's Access to China Market

Shanghai Free Trade Area is the first free trade area in China. It initiated a new investment access system called "Exclusive List for Foreign Investment". Proposed foreign investment projects which are within the scope of this Exclusive List will not be ratified by relevant Central authorities, Shanghai authorities or local authorities. On the other hand, if the business scope of any proposed foreign investment projects is beyond the scope of this Exclusive List, these projects will be allowed to establish business in Shanghai Free Trade Area as long as these projects also meet other required conditions. This Exclusive List offers more transparency for foreign investors and is helpful for foreign investors to consider their proposed business scope in this free trade area. Following the pilot reform experiences offered by Shanghai Free Trade Area, China rapidly implemented this good practice to other new free trade areas. Up to April 28 of 2018, China has already ratified 12 free trade areas ${ }^{40}$ (including Hainan Free Trade Area). In Circular 39, Chinese central government decides to expand this Exclusive List system to other nation-wide areas.

In Circular 39, China central government decides to further deepen its market openness to foreign capital in more manufacturing industries and service industries, which include specific automobiles and new energy automobiles manufacturing industry, vessel design industry, regional aircraft and airplane maintenance and repair industry, international maritime transport industry, railway passenger transport industry, gas station industry, place of business for providing internet access service, call centre industry, performance brokerage industry, banking industry, securities industry and insurance industry. The openness timetable and path will be clarified later by China central government.

\subsubsection{Introduction of New Fiscal and Tax Preferential Policies}

Circular 39 contains three tax preferential policies aimed to stimulate foreign capital in-flow to China. The first policy is to suspend the imposition of withholding tax on dividend which should have been paid by

40 The first batch of free trade area is Shanghai Free Trade Area which was ratified in year 2013. The second batch of free trade areas include Tianjin, Fujian and Guangdong free trade area, which were ratified in year 2014. The third-batch free trade areas include Liaoning, Henan, Zhejiang, Hubei, Chongqing, Sichuan, Shanxi free trade areas. The fourth batch of free trade area is Hainan free trade area, which was ratified in year 2018. 
a China resident company to its foreign investor/(s) but the foreign shareholder/(s) chooses to reinvest this dividend to China's investment projects under Encouraged Category. Prior to this preferential tax policy, foreign investor who receives dividend from China resident company should pay withholding tax at $10 \%$ rate according to China domestic tax law, unless otherwise stipulated by double tax convention.

The second policy is to expand the applicable areas for the corporate income tax reduced rate of $15 \%{ }^{41}$ granted to technologically-advanced service enterprises ${ }^{42}$ from former 31 pilot reform cities that are categorized as service outsourcing pilot cities to other areas in China.

The third policy is to implement the amended tax credit policy for overseas income, which is repatriated back to China by China's resident company (including multinational company's headquarters) which does business abroad. Under residence jurisdiction, the overseas-sourced income will be combined with domestic-sourced income for corporate income purpose. In order to further clarify this tax treatment for overseas income, the Ministry of Finance and the Taxation Administration released one notice namely "The Notice Aimed to Clarify the Tax Credit Policy for Enterprise's Overseas Income" (Circular Caishui [2017] 84, later called as "Circular 84") on 28 December 2017 but stressed this notice be enforced since 1 January 2017 (note: earlier than the issuance date of this notice). Under Circular 84, the tax credit includes two options: country-by-country method and comprehensive credit method. The China resident company may choose one option from these two options. When calculating the creditable tax and the credit limitation, the resident company is allowed to calculate 5 tiers of foreign companies where the China resident company

${ }^{41}$ Normal corporate income tax rate in China is 25\%. According to Circular Caishui [2017] 79, since 1 January 2017, the certified technologically-advanced service enterprise enjoys a reduced CIT rate of $15 \%$.

${ }^{42}$ The technologically-advanced enterprises should meet requisite conditions: 1) being registered in China in the form of a legal person enterprise, exclusive of enterprises registered in Hong Kong, Taiwan and Macau; 2) running business which is categorized as one or more than one of the technically-advanced services specified in the "Certified Scope of Technologically-advanced Services (Pilot Implementation)", and adopting advance technology or having strong R\&D capability; 3 ) the number of employees holding college diploma or higher diploma exceeding $50 \%$ of the total employee number; 4 ) the income sourced from these technologically-advanced business being more than $50 \%$ of the total annual income; 5) the income sourced from offshore out-sourcing services being not less than $35 \%$ of the total annual income. 
should directly or indirectly hold these foreign companies and the holding shares in each foreign company should not be less than $20 \%$ of its equity.

Besides tax preferential policies, China central government also formulates several fiscal measures to attract foreign capital in-flow. In Circular 39, regional governments are encouraged to offer fiscal funds aimed to attract multinational companies' headquarters. Fiscal funds also plays an important role in supporting the western China region and North East China region to improve their national-level development zones (including economic and technology zones, hi-tech industrial development zones, custom special captive zones, etc.) in terms of technological innovation, ecological environment protection, and provision of public services. The improvement in these regions' investment environment is to encourage foreign invested enterprises to transfer their capital and manufacturing bases from eastern China to China's western region and north east regions (both being less developed regions compared with eastern China).

Since purely reliance on fiscal funds is not sufficient to cover the huge costs of constructing infra structures in national-level development zones, the central government also encourages provincial governments to issue local governmental bonds in order to support the construction of both infrastructure and key projects in national-level development zones, economic cooperation zones located along the border and cross-border economic cooperation zones. Local governments are also allowed to issue project-oriented local governmental specific bonds provided the proposed projects are possibly able to pay off its current financing costs with its yields in the following years.

\subsubsection{Policies to Improve the Investment Environment} in Development Zones

According to Circular 39, China central government also expresses its intention to authorize national-level development zones with more investment administration autonomy. In order to ensure new foreign investment projects have sufficient business premises or business places in national-level development zones, central government via Circular 39 allows regional governments to guarantee land supply to foreign investment projects under the condition of meeting regionally social and economic development plan, regionally overall plan on land usage and overall municipal plan. The central government also permits national-level development zones to adjust its zone area, expand its zone area, integrate with its neighbouring development areas, build up enclave parks / zones and offer facilities and simplified 
procedures in making adjustments to the zoning plans for their newly purchased low-utilization lands. The central government also encourages some regions, which have available foundation to attract technologically-advanced foreign enterprises into their development zones, to carry out high-tech and high value added maintenance and repair business for domestic and overseas clients, and by this means extend their processing trade to the middle end or high end of the global supply chain.

\subsubsection{Policies to Facilitate Qualified Expatriates' Entry to China}

As stipulated in Circular 39, the central government decides to implement work permit system for expatriates, enlarge the expatriate visa issuance scope and prolong the visa valid duration. For expatriates who meet the specified conditions, issuance of multiple entry and exit visa with a valid period of 5 year or 10 years is also permitted, and what makes it better is that this long-term visa could serve as an evidence of approval for the application of work permit and work-linked residence permit.

\subsubsection{Policies to Optimize the Environment for Doing Business}

Under Circular 39, central government also adopts some measures to improve the business environment for foreign investment. First of all, the laws and regulations for domestic capital and foreign capital should be unified. Secondly, a response mechanism to address various complaints by foreign enterprises will be improved. Foreign enterprises shall be entitled to share the same citizenship treatments as domestic enterprises and their interests shall be protected. A unified and open market environment to protect orderly competition shall be established. In order to ensure no extra fees or charges be imposed on foreign enterprises, the government will establish a system to list all the fee items, inclusive of governmental fees and public institutional charges, governmental funds ${ }^{43}$ as well as profit-making service fees charged to enterprises but still complying with the pricing standards set by the government. Besides the above measures, central government also

${ }^{43}$ In China, governmental funds consist of harbour construction fee, railway construction fund, civil aviation development funds, etc. These governmental funds are surcharges imposed for the use of infra structures financed and constructed by central or regional governments. These governmental funds are charged mainly for the purpose of recovering the costs of constructing and maintaining these infra structure. In this sense, they shall be viewed as user fees or earmarked taxes. 
formulates other policies for foreign enterprises, such as to guarantee the free repatriation of profit back to foreign investors' overseas jurisdictions, to establish an administration information sharing and business coordination system among various government authorities, to encourage foreign capital to participate in the acquisition and merger of domestic enterprises, to improve the protection of foreign enterprises' intellectual property, to facilitate the R\&D activities carried out by foreign enterprises and create a globally competitive environment for doing research. Finally, regional and local governments should meet the policy commitments made to foreign investors or foreign enterprises and promise to perform various agreements signed between the governments and the foreign investors.

\subsection{Other Tax Concession Policies for Domestic and Foreign Capital}

As an active response to the US tax cut reform initiated by President Trump and also as an approach to improve the overall investment environment for both domestic and foreign capital in China market, Ministry of Finance and Tax Administration of China have released a few tax cut policies since January of year 2018, These tax cut policies involve either corporate income tax or value added tax in China, both of which are the major taxes in China.

For instance, the deductible training expenses for employees have been increased from $2.5 \%$ of the total salary cost to $8 \%$ of the salary cost since 1 January 2018 according to the Circular Caishui [2018] No. 51 ${ }^{44}$. In order to encourage enterprises to invest more in acquisition of equipment and devices ${ }^{45}$, the new equipment and devices acquired during the period from 1 January 2018 to 31 December 2020 with the total amount being not more than RMB 5 million are allowed to enjoy one-off deduction of the procurement cost for the corporate income tax purpose for that year when they are purchased, without need to compute the depreciation expenses annually as it did in the past. The cost of purchasing new equipment and devices exceeding RMB 5 million is still subject to the annual depreciation and deduction rule.

${ }^{44}$ See Circular [2018] No. 51 namely “The Notice on the Deduction of Enterprises' Employee Training Expenses before Tax by Ministry of Finance and Taxation Administration" entering into force as of 1 January 2018.

45 Equipment and devices refer to fixed assets exclusive of buildings and structures. 
The standard tax rate for value added tax has also been reduced from $17 \%$ to $13 \%$ and the reduced tax rate for value added tax has also been reduced from $11 \%$ to $9 \%$ since 1 April $2019^{46}$.

4. Major Characteristics of China Governments' Reaction to OfFset the Erosion of Competitiveness in Attracting Foreign Capital In-flow

In nowadays China, both the central government and regional governments pay much attention to offset their decline in the attractiveness to foreign capital. In order to better implement the notices issued by the central governments such as Circular 5 and Circular 39, regional governments have also formulated relevant detailed implementation rules and some of them also tailor made some new regional measures to make use of their regional comparative strength.

Central and regional governments' efforts could be divided into five categories: provision of protection to foreign capital, provision of guidance for the cultivation of industries and development zones, building platforms to attract foreign capital and foreign projects, deepening market openness and liberalization, and performing resources allocation.

China central government and regional governments initiate or emphasizes some policies to protect foreign capital's legal interests. These protection policies consist of: creation of a fair competition environment for both domestic and foreign capital; improvement in public services, protection of foreign enterprises' intellectual properties; reduction of business operation costs by tax cut and removal of governmental fees / funds; curbing and punishing the undue behaviours of local governments which do harm to or cause negative effects on foreign investments; pushing local governments to perform the agreements signed with foreign enterprises and offering to foreign enterprises the promised benefits which have been written in the mutual agreements between local government and foreign enterprises.

Both central government and regional government possess a unique advantage called as "information advantage". The information advantage means both central government and regional government master more statistical

46 See Notice No. 39 [2019] namely “The Notice on Relevant Policies of Deepening VAT Reform” issued by Ministry of Finance, General Administration of Taxation, General Administration of Customs on 20 March 2019. 财政部 税务总局 海关总署”关于深化 增值税改革有关政策的公告”财政部 税务总局 海关总署公告2019年第39号 
information and available research works regarding how to select and how to foster one or more than one pillar industry and how to cultivate dominant development zones. This is not hard to imagine, since in China every year the official statistic bureaus will collect numerous statistics. Furthermore, enterprises based in China are also required to file their tax returns, custom declaration forms to tax authorities and customs. Public universities and research institutions are liable to submit their research reports and policy proposals to their biggest sponsor - the government at various levels. And officials from various level of governments also do survey, on-site visit and interview to representative enterprises and development zones. The numerous information collection channels mentioned above guarantee the central and regional governments have comparative advantages in offer guidance on formulating national and regional industry development plans and also development plans for nation-level development zones.

China central government and regional governments are very proactive in building up platforms to attract foreign capital and foreign projects. This government function is rooted in China governments' another unique advantage - good reputation, image and credit. Compared with other countries' governments, China's central and regional governments are much wealthier in term of annual fiscal revenue or the total value of public assets. This good image means China governments are worthy of trusting, especially worthy of trust from foreign capital market and from foreign investors. China's central government and regional governments are clear aware of this advantage and have emphasized to organize more platforms to attract foreign capitals. These platforms include but not limited to international exhibitions, conferences, various commercial unions organized by overseas Chinese people, the official websites of the Ministry of Commerce and its subordinate branches.

The last function undertaken by China central government, regional governments and local governments is resources allocation. According to the above mentioned Circular 5, Circular 39 and detailed rules set by regional governments aimed to follow up these two circulars, regional governments promise to offer or at least symbolically show up their supports to several kinds of important production factors - available lands, capital and high-level talents.

In current China, due to its unique land ownership system, government is almost the only one legal supplier of lands to enterprises. According to Circular 39 and relevant regional detailed implementation plans to follow up Circular 39, eighteen provinces out of twenty-four provinces who 
formulated these follow-up plans offer to supply state-owned industrial lands at a discounted price (only equal to $70 \%$ of the fair market value ${ }^{47}$ ) to foreign projects which are categorized as "Encouraged Category" 48 Guangxi $^{49}$, Ganshu $^{50}$, Hunan ${ }^{51}$ and Sichuan ${ }^{52}$ province also promised to

${ }^{47}$ Foreign investment projects under encouraged category and with intensive land utilization are given priority in request for supply of land, and also are charged a land transfer fee at a favourable price, which should not be lower than $70 \%$ of the lowest price of the national industrial land at the similar land grade.

48 Every province shares the same or similar definition for the encouraged category of foreign invested projects or preferred foreign invested projects, except for minor variation. For instance, Guangxi, Hebei, Anhui, Ganshu, Jilin, Jiangxi, Liaoning, Qinghai, Shandong, Sanxi, Shanxi, Sichuan, Tianjin and Xinjiang call these preferred projects as "Encouraged Category Foreign Invested Projects", which refers to the encouraged projects under the "Guide Catalogue for Foreign Investment Industries". Henan, Jiangsu and Zhejiang province refer these encouraged projects as strategic new industries, advanced manufacturing industries which fit to their industry orientation and meet the criteria of intensive land usage. $\mathrm{Hu}$ nan province expands the scope of encouraged projects, including both encouraged foreign investment projects and its provincially advantageous projects falling within the Catalogue for Advantageous Foreign Investment Industries in Central and Western Regions as well as Key Industrial Guide Catalogue for Hunan Province's Attraction of Capital Inflow.

49 Guangxi government charges land transfer fee to foreign invested enterprises at a favourable price, which should not be lower than $50 \%$ of the lowest price of the national industrial land at the similar land grade, for their projects of which the land usage complies with the overall land usage plan and the lands are unused lands of which the location is within the land development key areas set by the overall land usage plan.

${ }^{50}$ Ganshu government allows to charge a land transfer fee at a favourable price, ranging from $15 \%$ to $50 \%$ of the lowest price of the national industrial land at the similar land grade, for the unused lands. The duration of the installment payment of the land transfer fee written in the land transfer contract between the municipal or county's state land resources administration bureaus shall not exceed one year. Upon the collective ratification by local land transfer coordination and decision institution, the land transfer fee for special projects shall be paid off within two years. The down payment shall not be less than $50 \%$ of the total land transfer fee.

${ }^{51}$ Hunan government stipulates that the state-owned used lands beyond the scope of urban construction lands where the latter were determined by the overall land usage plan, and also the preliminary phase of land development is to be solely finished by the land user, may be charged at not less than $15 \%$ of the standard fee in view of the land locality and the land grade it belongs to. When the foreign investment projects use the stateowned lands falling within the scope of urban construction lands which are determined by the overall land usage plan, the land transfer fee may be charged at a price not less than $50 \%$ of the standard fee in view of the land locality and the land grade it belongs to.

${ }^{52}$ Sichuan government stipulates that the lowest price standard for unused industrial lands shall range from $10 \%$ to $50 \%$ (with the exact discount percentage depending on its actual situation) of the lowest price standard for the national industrial land. 
supply undeveloped or unused lands to foreign projects at even lower prices which are only equal to $50 \%, 15 \%$ or even $10 \%$ of the fair market price (note: in practice the concrete discount is depending on the case by case negotiation with regional local governments).

Capital is an important production factor. In response to Circular 5, regional governments formulate detailed measures to offer financial support to foreign enterprises. For example, Shanghai government formulated financial support measures to attract foreign capital. According to Article 18 of its follow-up plan namely "Several Comments on Further Expansion of Openness and Speeding up the Establishment of Open-oriented Economic New System" issued by Shanghai government (Circular Hufufa [2017] No. 26), Shanghai determines to take advantage of its strength in having multiple levels of capital market - supporting qualified foreign invested enterprises to restructure and afterwards do initial public offering (IPO) in stock market, issue bonds, develop asset backed securitization, trade in the new overthe-counter market or trade in the Shanghai equity trusteeship and trading centre. Shanghai government encourages foreign invested enterprises to optimize their financing structure and financing forms by using various financing forms such as ordinary stock, preferential stock, convertible stock and company stock, which are aimed to improve their capital structure and reduce their financing costs. Financial institutions in Shanghai are encouraged to offer financing services. Qualified foreign enterprises are allowed to borrow foreign-sourced funds in the form of loans which are denominated in domestic currency or in foreign currency ${ }^{53}$, etc.

High-level talent is the key production factor in current China, especially when the officials of China governments realizes the most possible way China could take to keep its economic growth is to improve its production efficiency rather than purely increasing its capital input or labour input, since the marginal production return rate will diminish when an enterprise continues to increase its capital input given the input of other factors remain unchanged. Obviously in current China its capital is in a relatively surplus situation, characterized by its massive-capital-export through "One Belt One Road". It is impossible for China in the forthcoming years to increase its labour input under the population aging trend in China. Thus the only way to remain economic

53 Currently China has not yet allowed liberal capital flow into and out of its territory. Hence China resident company intending to borrow debt shall be subject to foreign exchange regulation to a certain extent. 
growth is to upgrade its industries by adopting more advanced technologies and recruiting well educated and trained work force. In order to attract these high level talents, regional governments in China formulate some policies inclusive of providing fiscal subsidy to these talents for the purpose of supporting their research work. For instance, Jiangsu province implements provincial "Double Innovation Plan" and "Phoenix-Comes-Back-to-its-Nest Plan" as well as Jiangsu "One Hundred Foreign Experts Plan", which are aimed to attract high level innovation talents and business-starting talents and teams inclusive of strategic scientists, chief scientists and technological-oriented businessmen. Jiangsu province also implements a plan under which top talents are entitled to top supports, where the first class teams introduced from all over the world will be subsidized with funds with the maximum budget for each project set at RMB 100 million $^{54}$. Guangxi Zhuang Autonomous Region offers position allowance with its ceiling not more than RMB 1 million to overseas high level talents and also offers housing allowance with its ceiling not more than RMB 2 million. The qualified high level talents and the relevant teams will be also offered with research allowance funds with the ceiling not more than RMB 10 million ${ }^{55}$. Besides attracting high-level talents, central government and regional governments also offer chances for foreign enterprises to participate in research projects funded by governments.

\section{Critiques to China's Tax and Non-tax Policies Relative to Attracting Foreign Capital}

What are the possible effects of the above mentioned tax and non-tax policies? Some of the policies adopted by China governments are only tailored made for a specific group of taxpayers. Inevitably this will be criticized by other groups of taxpayers from the tax equity perspective or other perspectives. On the other hand, these policies will create some good effects either from the perspective of economic efficiency or fiscal transparency. The discussion on these effects is set out as follows.

China governments' involvement in resources allocation will cause many distortions. These distortions include rent-seeking (since not every

54 Article 7 of "Jiangsu Province Government's Comments on the Further Expansion of Openness and Proactive Use of Foreign Capital” (Circular Suzhengfa [2017] No. 33).

55 Article 7 of "Guangxi Zhuang Autonomous Region Government's Implementation Comments on the Further Expansion of Openness and Proactive Use of Foreign Capital" (Circular Guizhengfa [2017] No. 60). 
applicant / enterprise is qualified to enjoy fiscal subsidy), official corruption, inducing foreign enterprises to abuse resources on this subsidy lobby activities rather than allocate resources on real operation or $\mathrm{R} \& \mathrm{D}$, triggering the race to the bottom competition in term of fiscal subsidy among provincial governments or even local governments.

China's regional governments, particularly the central and western regional governments, are very keen on supplying available lands to attract foreign direct investment. In practice, China regional or local governments acquire agricultural lands from peasants by paying a price far lower than market price and afterwards supply these lands at an appealing price as an incentive to the foreign invested enterprises as long as their claimed investment scale or investment scope satisfy government's favoured criteria. Sometimes these acquisitions of agricultural lands are not agreed by local peasants (the sellers) and thus are not of peasants' economic interests. In some places, peasants losing their agricultural lands are unable to find any jobs in local job markets and hence unemployment becomes an inevitable result ${ }^{56}$ caused by this kind of land acquisition dominated by local governments. In this sense, China's land issue with respect to the land supply to development zones is similar to that in India ${ }^{57}$.

China does not have a similar rule as European Union's prohibition of state aid. This cause the absence of a mechanism to restrict China governments' intention to create new development zones, and to expand the size of development zones. China's regional governments always have a motivation to lobby the central government to ratify their applications for creation of new development zones or expansion of their existing development zones. China's central government also sees this as an effective or necessary instrument to enhance economic development and reverse spatial economic imbalance. After all, China's central government's decision to forming or expanding development zones is not subject to any supranational organization's constraint (i.e. European Union).

In China, this phenomenon of development zone booming was described as "development zone fever" in the aforementioned literature. The irrational creation and expansion of development zones lead to low utilization or even

56 张克俊/Zhang Kejun, 李瑛/Li Ying, 开发区失地农民就业问题研究/Study to the Employment Issue Linked with the Peasants Losing Their Lands for the Construction of Development Zones, “农村经济/Rural Economy” 2008, vol. 03, pp. 105-108.

57 See Parwez and Sen (2016). 
no utilization of the lands or infrastructures within these zones ${ }^{58}$. This is a great waste of economic resources. What makes it worse is that, some regional or local governments have borrowed numerous debts via the municipal investment companies under their control to construct urban infrastructure, including but not limited to the infrastructure within development $z^{2} e^{59}$. If some of these regional or local governments fail to attract enough foreign direct investment, as a result, they are unable to pay off the interests and principals of these debts. This brings relatively high financial risks to these regional or local governments. This is also a critical concern for China's central government since in case any regional governments are financially bankruptcy it is the obligation of the central government to offer rescue to them. Under the downturn trend of economy in the near future, this issue is becoming worse.

China government's various fiscal subsidies to foreign enterprises will possibly cause complaints from its other trading competitors such as the US and the EU member states who value free market, liberal economy and disfavour state aid. China governments' fiscal subsidies might lead to tension and conflict with its rivals in international trade or international investment.

\section{Positive Effects and Good Practice for Other Countries}

\subsection{Positive Effects of China's Tax and Non-tax Policies Relative to Attracting Foreign Capital}

China governments' various efforts in offering protection to foreign investment, providing guidance to regional development plan based on its information strength and expanding market openness as well as deepening

58 See: 卢新海/Lu Xinhai,开发区土地资源的利用与管理/The Use and Administration of Land Resources within Development Zones, “中国土地科学/China Land Science”, 2004, vol. 02, pp. 40-44; 何书金/He Shujin, 苏光全/Su Guangquan,开发区闲置土地成因机制 及类型划分/ The Formation Mechanism and Classification of the Types of Idle Lands within Development Zones, “资源科学/Resources Science” 2001, vol. 05, pp. 17-22; 龙开胜/Long Kaisheng, 秦洁/Qin Jie, 陈利根/Chen Ligen, 开发区闲置土地成因及其治理路径——以 北方 $A$ 市高新技术产业开发区为例/ The Cause of the Idle Lands within Development Zones and its Governance Path - Taking a High Technology Industry Development Zone Located in City A in Northern China as Example, “中国人口·资源与环境/China Population, Resources and Environment” 2014, vol. 24 (1), pp. 126-131.

59 Yoshiaki Azuma, Jun Kurihara, Examining China's Local Government Fiscal Dynamics: With a Special Emphasis on Local Investment Companies (LICs), "Cambridge Gazette: Politico-Economic Commentaries”, 3 January 2011, no. 5, pp. 1-19. 
market liberalization are within the scope of traditional government's functions. These measures generate positive spill-over effects, remove investment obstacles or loosen administration regulations for foreign capital. These measures offer facility to enterprises and also are helpful to reduce foreign enterprises' manufacturing costs and operation costs.

From economic perspective, the positive effects of these policies could be summarized as the improvement of enterprises' profitability. These measures lead to the reduction of enterprise transaction costs, which arises in the course of establishing and operating a physical presence in China. These transaction costs generally include compliance cost and operation cost incurred in China (i.e. land cost, high level employees' salary costs, $\mathrm{R} \& \mathrm{D}$ costs) and also international trading cost (i.e. custom declaration procedures, foreign exchange settlement procedures and the relative time cost and custom compliance cost as well as foreign exchange compliance cost).

These policies of removing investment obstacles and simplifying governments' administration procedures and documentation requirements improve China's transparency in business environment and also enhance China market's fairness in competition between domestic capital and foreign capital. From economic perspective, these transparency policies are economically efficient since transparency is helpful to reduce investment uncertainty and consequently controls the possibility of making losses in investment. The market fairness improvement policies are also economically efficient because under this fair mechanism the most efficient entities in the market are more likely to win and on the other hand the less efficient entities are more likely to lose. This mechanism is good to recover the market's inherent market clearance function and undoubtedly this would in a long run lead to the overall improvement in the whole nation's economic efficiency.

6.2. Implications of China's Practice to Other Countries in the World

In the long run, tax incentives will serve the economic stimulation purpose under special circumstances but implementation of tax incentives aimed to develop economy should be subject to very strict economic constraint conditions, i.e. having millions of idle work-force population, having competitively cheap idle lands, having friendly market environment and not causing unaffordable tax inequity or spatial economic imbalance 
or industrial disparity. When one or some of these necessary constraint conditions changes, the feasibility of introducing these tax incentives will be weakened, which in turn will cause the weakening of these tax incentives' justification in term of legislation. This also could explain why China's zone-based and foreign-oriented preferential tax policies in its earlier stage have achieved positive effects inclusive of pushing economic growth and employment rise. This also could explain why China in its later stage phased out these preferential tax policies, since China could not satisfy some of the necessary constraint conditions in its later phases, i.e. lacking millions of idle and cheap human resources due to population aging, lacking available cheap lands, worsened tax equity between foreign capital and domestic capital, unaffordable regional economic imbalance in China's later phases of economic openness and development. These pre-conditions to implement special tax zones also apply to other countries in the world. The fact that these special tax zones are more popular in developing economies than developed economies nowadays is a good evidence to prove the applicability of these pre-conditions. This could induce one conclusion that tax incentives for special tax zones should exit in a specific historical period rather than existing during a long-lasting period and this conclusion has been supported by China's practice in the past forty years and might hopefully be supported by Poland's phasing out of its tax incentives for special tax zones in year 2020 .

Theoretically, similar entities under the same situations in the market should enjoy the same tax policy, which is generally called as "no tax discrimination". The introduction of special tax incentives to foreign capital enterprises, particularly those situated in captive economic zones should be justified with strong reasons, otherwise would lead to critiques from domestic capital enterprises. The most persuasive rationale to justify these tax incentives is that these tax incentives could stimulate economic boom and generate positive spill-over effects such as creating more employment opportunities to idle work-force resources, or establishing regional pillow enterprise / industry, which is dominated by foreign capital, can create many matching service or matching supply opportunities for domestic local enterprises.

However, after the global financial crisis in year 2008, the investment return rate of China's manufacturing sector has undergone gradually decreasing. This decline in investment return rate is caused by the increasing land cost, rent cost, labour cost, logistic cost as well as public service 
costs (in term of tax burden and non-tax user fee burden and non-tax levy burden borne by enterprises carrying on business in China). These increased costs eroded China enterprises' possible profit before tax. The rapid rise in the price of almost every production factor has significantly eroded China's attractiveness to labour-intensive industries. A significantly portion of these industries are concentrated in the eastern coastal regions of China due to historical reasons and more specifically speaking, concentrated in various development zones in eastern coastal regions of China. Many foreign capital enterprises in China have already considered or are considering to moving out of China and then establish new premises in Vietnam, Malaysia, India or other south eastern Asian or south Asian countries. Even though China implements some favourable tax policies to enterprises again (however much less generous compared with its previous preferential tax policies entitled to foreign invested enterprise) like it did in the past for foreign invested enterprises, it could only postpone or prolong this foreign capital outflow process but cannot change its overall trend in the long run since foreign capital is always seeking for the maximization of investment return rate.

In order to deal with the weakening in its competitiveness in attracting foreign capital, China government adopts two approaches. One approach is from the supply side, i.e. emphasizing the reduction of the cost of doing business for foreign invested enterprises. The reduction of costs was realized by China government by granting some new favourable tax treatments involving reducing the tax rate and narrowing the tax base, reducing compliance costs and also reducing the production factor prices within its controllable extent, such as reducing the state-monopoly land supply prices, and implementing financing policies via its control on the state-controlled banks and financial institutions as well as reducing the cost of hiring high level talents by subsidizing these personnel. Since China governments possess or have control / influence on many economic resources under current state-ownership and public-ownership economic system, it has more than one option to help reduce the cost of doing business for foreign invested enterprises.

The other approach is from the demand side, which means China governments, as existing public procurement clients of these foreign invested enterprises, offer many business orders to them, including scientific research projects, infra structure construction projects, and other projects involving the construction and development of various development zones. This demand side approach is based on China governments' comparative 
strength of having abundant fiscal revenues and large sized public expenditures compared with most of the economies in the world.

The other finding of this paper lies in its analysis on the economic foundation which makes these non-tax measures feasible. This economic foundation mainly consists of China's comparative advantages: having unique public ownership system (land, major financing channel controlled by the governments) and having abundant fiscal revenues as well huge foreign exchange reserve accumulated through its long-term international trading surplus.

Adoption of non-tax measures and making use of comparative advantage are the major characteristics of China's solution to address its weakening in attractiveness to foreign capital. China's practice in this regard offers valuable lessons for other countries since some of these countries also are confronting with the challenge of remaining their competiveness in attracting foreign capital. China governments' choice of relying more on non-tax measures rather than relying on purely tax measures is also a good practice which succeeded in refraining from conducting harmful tax competition. This good practice also is of reference value to other countries in the world for the sake of avoiding harmful tax competition, especially when curbing of harmful competition has become a consensus to most of the major economies in the world.

\section{BIBLIOGRAPHY}

Ahrens J., Meyer-Baudeck A., Special Economic Zones: Shortcut or Roundabout Way towards Capitalism, "Intereconomics”, March / April 1995.

Azuma Y., Kurihara J., Examining China's Local Government Fiscal Dynamics: With a Special Emphasis on Local Investment Companies (LICs), "Cambridge Gazette: Politico-Economic Commentaries", 3 January 2011, no. 5.

Bräutigam D., Tang X., "Going Global in Groups”: Structural Transformation and China's Special Economic Zones Overseas, "World Development” 2014, vol. 63.

Huang J., He C., Wei Y.H.D., A Comparative Study of Efficiency of Electronics Firms Located within and outside Development Zones in Shanghai, "Habitat International" 2016, vol. 56.

Jarosiński K., Maśloch G., The Impact of Special Economic Zones on the Level of SocioEconomic Changes of Polish Regions, Warsaw Forum of Economic Sociology, Autumn 2016, vol. 7, no. 2 (14).

Journalist Du T., The Differential in Financing Costs Among Enterprises Is Big, and the Difficulty and High Cost in Financing for Medium and Small Size Enterprises are more and more Notable, Published on "Economic Observer", https://finance.sina.cn (accessed: 7.05.2018). 
Laukkanen A., The Development Aspects of Special Tax Zones, "Bulletin for International Taxation" 2016, vol. 70, no. 3.

Lipták F., Klasová S., Kováč V., Special Economic Zone Constitution According to Cluster Analysis, "Procedia Economics and Finance" 2015, no. 27.

The Notice on Relevant Policies of Deepening VAT Reform (财政部 税务总局 海关总 署公告2019年第39号/ Notice No. 39 [2019] issued by Ministry of Finance, General Administration of Taxation, General Administration of Customs).

Parwez S., Sen V., Special Economic Zone, Land Acquisition, and Impact on Rural India, "Emerging Economy Studies" 2016, vol. 2 (2).

Smętkowski M., Polish Special Economic Zones as an Instrument of Regional and Industrial Policy, "Munich Personal RePEc Archive”, http://mpra.ub.uni-muenchen.de/39184/ (accessed: 15.04.2018), MPRA Paper No. 39184, posted on 19 June 2012.

Sosnovskikh S., Industrial Cluster in Russia: The Development of Special Economic Zones and Industrial Parks, "Russian Journal of Economics" 2017, vol. 3.

Wang J., The Economic Impact of Special Economic Zones: Evidence from Chinese Municipalities, "Journal of Development Economics" 2013, vol. 101.

Wu X., Foreign Capital Is Flowing Out of China and Why?, "Finance and Economy First We Media - Wu Xiaobo Channel", 6 May 2018.

Zhang J., Interjurisdictional Competition for FDI: The Case of China's "Development Zone Fever", "Regional Science and Urban Economics" 2011, vol. 41.

Zheng G., Barbieri E., Tommaso M., Zhang L., Development Zones and Local Economic Growth: Zooming in on the Chinese Case, "China Economic Review" 2016, vol. 38.

何书金/He S., 苏光全/Su G., 开发区闲置土地成因机制及类型划分/ The Formation Mechanism and Classification of the Types of Idle Lands within Development Zones, “资源科学/Resources Science” 2001, vol. 05.

龙开胜/Long K., 秦洁/Qin J., 陈利根/Chen L., 开发区闲置土地成因及其治理路 径——以北方 $A$ 市高新技术产业开发区为例/ The Cause of the Idle Lands within Development Zones and its Governance Path - Taking a High Technology Industry Development Zone Located in City A in Northern China as Example, “中国人口·资源 与环境/China Population, Resources and Environment” 2014, vol. 24 (1).

卢新海/Lu X., 开发区土地资源的利用与管理/The Use and Administration of Land Resources within Development Zones, “中国土地科学/China Land Science” 2004, vol. 02.

张克俊/Zhang K., 李瑛/Li Y., 开发区失地农民就业问题研究/Study to the Employment Issue Linked with the Peasants Losing Their Lands for the Construction of Development Zones, “农村经济/Rural Economy” 2008, vol. 03. 


\section{PODATKOWE I NIEPODATKOWE INSTRUMENTY ODPOWIEDZIALNE ZA OSŁABIENIE ATRAKCYJNOŚCI CHIN}

\section{Z PERSPEKTYWY ZAGRANICZNEGO KAPITAEU}

Streszczenie. W artykule przeanalizowano kwestie związane z osłabieniem atrakcyjności Chin z perspektywy zagranicznego kapitału, po wprowadzeniu w 2008 r. nowych regulacji dotyczących podatku dochodowego od osób prawnych, które zlikwidowały wcześniejsze preferencje podatkowe dla zagranicznych inwestorów oraz wprowadziły korzystne instrumenty polityki podatkowej dla różnych rodzajów specjalnych stref podatkowych. W artykule przedstawiono empiryczne dowody i główne czynniki powodujące osłabienie przyciągania inwestycji zagranicznych. Przeanalizowano w nim także główne narzędzia podatkowe i środki pozapodatkowe przyjęte przez chiński rząd centralny i władze regionalne, których celem jest poprawa konkurencyjności Chin w zakresie przyciągania zagranicznego kapitału. Głównym wkładem tego artykułu jest dyskusja na temat dobrych praktyk Chin w zakresie wykorzystywania środków niepodatkowych w celu przyciągnięcia kapitału zagranicznego, co skutecznie zapobiega szkodliwej międzynarodowej konkurencji podatkowej. Innym wkładem tego artykułu jest dyskusja na temat podstaw ekonomicznych (tj. chińskiej siły porównawczej i własności państwowej gruntów), dzięki którym te środki pozapłacowe są wykonalne. Dobra praktyka Chin w zakresie przyjmowania środków niepodatkowych i wykorzystywania ich siły porównawczej ma wartość odniesienia dla innych krajów importujących kapitał na świecie.

Słowa kluczowe: atrakcyjność dla kapitału zagranicznego, środki pozapłacowe, przewaga komparatywna 